\title{
BLOCK OF HAMSTER FERTILIZATION BY ANTI-OVARY ANTIBODY
}

\author{
T. OIKAWA* AND R. YANAGIMAGHI \\ Department of Anatomy and Reproductive Biology, \\ University of Hawaii School of Medicine, \\ Honolulu, Hawaii 96822, U.S.A.
}

(Received 6th March 1975)

\begin{abstract}
Summary. Antibody produced in rabbits against hamster ovary blocked fertilization of golden hamster eggs in vitro by binding to the surface of the zona pellucida and rendering it impenetrable to spermatozoa. The antibody was also effective in blocking fertilization in vivo. An intraperitoneal injection of the antibody into females resulted in the complete inhibition of fertilization for approximately 12 days, i.e. three oestrous cycles. This temporary sterility was apparently due to the binding of the antibody to the zona pellucida of oviducal and ovarian oocytes, and not due to a failure of sperm ascent or capacitation in the female genital tract. Neither the oestrous cycle nor ovulation was affected by the antibody injection.
\end{abstract}

\section{INTRODUCTION}

Ownby \& Shivers (1972) have reported that antiserum produced in rabbits against hamster ovary contains at least one antibody specific to the ovary. This antibody, when tested on hamster eggs in vitro, causes a precipitation of the outermost layer of the zona pellucida and renders it resistant to trypsin digestion (Ownby \& Shivers, 1972). Further studies (Shivers et al., 1972; Garavagno $e t$ al., 1974) have shown that the precipitation of the zona surface by the antibody prevents spermatozoa from attaching to and penetrating the zona pellucida, thus effectively blocking fertilization in vitro. The species-specificity of the antibody has been documented (Garavagno et al., 1974). We report here that the anti-ovary antibody (antiserum) blocks fertilization not only in vitro, but also in vivo.

\section{MATERIALS AND METHODS}

\section{Anti-ovary serum}

Antiserum against the golden hamster ovary was prepared according to the method of Ownby \& Shivers (1972) and Garavagno et al. (1974) with some modifications. Ovaries of ten adult hamsters in various stages of the oestrous

\footnotetext{
* Present address: Department of Biology, Faculty of Science, Yamagata University, Yamagata, Japan.
} 
cycle were placed in about $2 \mathrm{ml}$ tris-saline $(0.01 \mathrm{~m}$ tris-HCl- $0.9 \% \mathrm{NaCl}, \mathrm{pH}$ $7 \cdot 4$ ) and homogenized for $5 \mathrm{~min}$ at $0^{\circ}$ to $4^{\circ} \mathrm{C}$. The homogenate was centrifuged at $2500 \mathrm{~g}$ for $20 \mathrm{~min}$ and the supernatant was separated from the sediment. The volume of the supernatant was adjusted to $2.0 \mathrm{ml}$ with tris-saline, mixed with an equal volume of Freund's complete adjuvant (Difco Laboratories, Detroit, Michigan) and emulsified. Two $\mathrm{ml}$ of this emulsion were injected intramuscularly into a male rabbit. The second and third injections of the emulsion (emulsion was prepared using fresh ovaries every time) were given at weekly intervals and the animals were killed 10 days after the third injection. Blood was collected by heart puncture and the serum isolated was heated at $56^{\circ} \mathrm{C}$ for $30 \mathrm{~min}$.

\section{$\gamma$-Globulin fraction of anti-ovary serum}

The anti-ovary serum was mixed with an equal volume of an aqueous, saturated solution of ammonium sulphate and centrifuged at $8000 \mathrm{~g}$ for $20 \mathrm{~min}$ at $4^{\circ} \mathrm{C}$. The precipitate was washed twice by centrifugation $(20,000 \mathrm{~g}$ for $20 \mathrm{~min}$ each) with saturated ammonium sulphate solution and dissolved in tris-saline. The solution was dialysed against tris-saline for $24 \mathrm{hr}$ at $4^{\circ} \mathrm{C}$ and concentrated by means of a collodion bag apparatus (Scientific Products, McGaw Park, Illinois) until the protein concentration (determined by u.v. absorption) was 20 to $50 \mathrm{mg} / \mathrm{ml}$. This preparation containing a crude $\gamma$-globulin fraction of the serum (Sacco \& Shivers, 1973a) was called anti-ovary serum fraction or AOSF, and was used in experiments immediately after preparation. Part of the AOSF was absorbed with lyophilized hamster ovary, uterus or small intestine and lung as described by Ownby \& Shivers (1972). In this paper, AOSF refers to the $\gamma$-globulin fraction of non-absorbed anti-ovary serum unless otherwise stated.

\section{Control serum and its $\gamma$-globulin fraction}

The control serum and its fraction were prepared in the same manner as described above, but from the blood of non-immunized rabbits. The $\gamma$-globulin fraction of this serum was called control serum fraction or CSF.

\section{Fluorescein-conjugated AOSF}

Fluorescein isothiocyanate $(0.5 \mathrm{mg})$ was mixed with $1 \mathrm{ml}$ AOSF containing $25 \mathrm{mg}$ protein. After the $\mathrm{pH}$ was adjusted to $9 \cdot 1$ with tris buffer, the solution was stirred constantly for 6 to $12 \mathrm{hr}$ at $4^{\circ} \mathrm{C}$. The conjugate was isolated from unconjugated dye by filtration through a Sephadex G-50 column.

\section{Collection of unfertilized eggs for in-vitro experiments}

Mature unfertilized eggs of the golden hamster, mouse (Swiss-albino) and rat (Fisher) were obtained as follows. Adult female hamsters were injected intraperitoneally (i.p.) with 20 to 30 i.u. PMSG (Ayerst Laboratories, New York) in the morning (09.00 to 11.00 hours) of Day 1 of the oestrous cycle, i.e. the day of ovulation (ovulation occurs in the early morning of Day 1; Greenwald, 1960, 1961). On Day 3, the animals were injected i.p. with 20 to 30 i.u. HCG (Ayerst Laboratories). Adult mice were injected with 5 to 10 i.u. PMSG regardless of 
the stage of the oestrous cycle followed by an injection of 5 to $10 \mathrm{i} . u$. HCG $48 \mathrm{hr}$ later. Prepubertal rats were injected with 20 to 30 i.u. PMSG followed by an injection of 20 to 30 i.u. HCG 48 to $56 \mathrm{hr}$ later. Between 15 and $17 \mathrm{hr}$ after injection of $\mathrm{HCG}$, the animals were killed and the oviducts were flushed with tris-saline. The eggs were freed from their surrounding cumulus cells by treating them for $15 \mathrm{~min}$ at room temperature with 0.1 to $0.2 \%$ bovine testicular hyaluronidase (300 USP units/mg: Nutritional Biochem., Cleveland, Ohio) in tris-saline.

In-vitro treatment of eggs with AOSF or CSF and subsequent in-vitro insemination and examination of eggs

Cumulus-free eggs were treated with tris-saline containing 20 to $50 \mathrm{mg} / \mathrm{ml}$ AOSF or CSF for $30 \mathrm{~min}$ at $35^{\circ} \mathrm{C}$, rinsed thoroughly with tris-saline and examined under dark-field illumination for light-scattering properties of the zona pellucida. Some eggs were exposed to $0.1 \%$ trypsin (2X crystallized, Type III, Sigma Chemicals, Saint Louis) or $0.1 \mathrm{~m}-2$-mercaptoethanol in trissaline for 30 to $60 \mathrm{~min}$ at $25^{\circ} \mathrm{C}$ and examined for dissolution of the zona pellucida. The zona pellucida of normal (untreated) hamster eggs is dissolved completely by these reagents within less than 5 min. Methods for in-vitro insemination of hamster eggs and evaluation of fertilization (sperm penetration) have been described previously (Oikawa et al., 1973, 1974).

\section{Artificial insemination and injection of AOSF or CSF into female hamsters}

Female hamsters were anaesthetized with ether in the evening of Day 4 of the oestrous cycle and a suspension of spermatozoa from the cauda epididymidis in Tyrode's solution was placed in the uterus. In normal females $100 \%$ or nearly $100 \%$ of the eggs should be fertilized and in the pronuclear stage the next morning (Yanagimachi, 1966). Either AOSF or CSF was injected i.p. into each oestrous female as described in the 'Results'.

\section{RESULTS}

Fertilization block in vitro

Fresh unfertilized eggs were treated with either AOSF (non-absorbed or absorbed) or CSF solutions. One group of eggs was tested for changes in the properties of the zona pellucida; the other group was tested for fertilizability by inseminating the eggs in vitro with capacitated, acrosome-reacted spermatozoa. The results are summarized in Table 1 . When the eggs were treated with nonabsorbed AOSF, the zona surfaces developed strong light scattering properties (Pl. 1, Fig. 1) and became resistant to trypsin and mercaptoethanol. Spermatozoa failed to bind to the zona surfaces and none of the eggs was penetrated. CSF did not induce any appreciable changes in the zona pellucida (Pl. 1, Fig. 2) and all the eggs were penetrated by spermatozoa. The zona-modifying and fertilization-blocking actions of AOSF were completely abolished when AOSF was absorbed with ovary, but not when it was absorbed with uterus or intestine and lung, indicating that the effective agent in AOSF is a specific anti-ovary antibody. The modification of the zona pellucida and prevention of fertilization 
Table 1. Effects of treatment for $30 \mathrm{~min}$ at $25^{\circ} \mathrm{C}$ with antisera fractions on hamster eggs in vitro

\begin{tabular}{|c|c|c|c|c|c|}
\hline \multirow{2}{*}{$\begin{array}{c}\text { Fraction } \\
\text { tested } \\
(20 \text { to } 50 \mathrm{mg} / \mathrm{ml})\end{array}$} & \multicolumn{2}{|c|}{$\begin{array}{l}\text { Properties of egg } \\
\text { zona after } \\
\text { treatment }\end{array}$} & \multirow{2}{*}{$\begin{array}{c}\text { No. of } \\
\text { eggs } \\
\text { inseminated }\end{array}$} & \multicolumn{2}{|c|}{ Eggs $2 \mathrm{hr}$ after insemination } \\
\hline & $\begin{array}{c}\text { Light } \\
\text { scattering* }\end{array}$ & $\begin{array}{c}\text { Resistance to } \\
\text { trypsin and } M E \dagger\end{array}$ & & $\begin{array}{l}\text { Sperm. attachment } \\
\text { to and penetration } \\
\text { into zona } \ddagger\end{array}$ & $\begin{array}{c}\text { No. }(\%) \text { of eggs } \\
\text { penetrated by } \\
\text { sperm. }\end{array}$ \\
\hline \multicolumn{6}{|l|}{$\begin{array}{l}\text { Anti-ovary } \\
\text { serum fraction } \\
\text { (AOSF) }\end{array}$} \\
\hline $\begin{array}{l}\text { Non-absorbed } \\
\text { Absorbed with }\end{array}$ & +++ & + & 40 & - & $0(0)$ \\
\hline uterus & ++ to +++ & + & 28 & - & $0(0)$ \\
\hline & $+t$ & + & 35 & - & $0(0)$ \\
\hline $\begin{array}{l}\text { Absorbed with } \\
\text { ovary }\end{array}$ & - & - & 40 & +++ & $40(100)$ \\
\hline $\begin{array}{l}\text { Control serum } \\
\text { fraction (CSF) }\end{array}$ & - & - & 42 & +++ & $42(100)$ \\
\hline
\end{tabular}

* Examined under dark-field illumination: very strong $(+++)$, moderate $(++)$, and no light scattering (-) by the outermost region of the zona pellucida.

$\dagger$ Treatment for $30 \mathrm{~min}$ with $0.1 \%$ trypsin or $0 \cdot 1$-M-mercaptoethanol. + , Failure to dissolve the entire zona within $30 \mathrm{~min}$; - , zona pellucida completely dissolved within 5 min.

$\ddagger$ Capacitated, acrosome-reacted spermatozoa fail to attach to and penetrate into the zona (-); many spermatozoa attach to and penetrate through the zona $(+++)$.

by the antibody appeared to be species-specific since the zonae pellucidae of mouse and rat eggs remained unchanged after treatment with AOSF (Pl. 1, Figs 3 and 4).

Fertilization block in vivo

In order to determine whether AOSF can block fertilization in vivo, oestrous female hamsters were naturally or artificially inseminated between 20.00 and 21.00 hours of Day 4 of the oestrous cycle. Approximately $1 \mathrm{hr}$ later a variable amount of either AOSF or CSF (equivalent to 4 to $50 \mathrm{mg}$ protein) was given to each female. The animals were killed at 10.00 hours the next morning and the eggs flushed from the oviducts were examined for evidence of fertilization. When females were injected with $40 \mathrm{mg}$ or more of AOSF, none of the eggs was penetrated by spermatozoa (Table 2), despite the fact that many actively motile, acrosome-reacted spermatozoa were collected from the oviduct at the time of egg recovery. The zona surfaces of these unfertilized eggs scattered light strongly under dark-field illumination and the outer region of the zona was resistant to trypsin and mercaptoethanol. Lower doses of AOSF (20 to $30 \mathrm{mg}$ protein/animal) partly blocked fertilization; a very low dose of AOSF (4 mg protein/animal) or any quantity of CSF (4 to $50 \mathrm{mg}$ protein/animal) was totally ineffective in blocking fertilization (Table 2).

Next, experiments were performed to find out how long AOSF maintains its fertilization-blocking action in vivo. Oestrous female hamsters were each given a single i.p. injection of AOSF (equivalent to $50 \mathrm{mg}$ protein/animal). Control animals were injected with CSF (equivalent to $50 \mathrm{mg}$ protein/animal). All the 
Table 2. Block to fertilization of hamster eggs in vivo* by anti-ovary serum fraction

\begin{tabular}{|c|c|c|c|c|c|}
\hline \multirow{2}{*}{$\begin{array}{l}\text { Fraction } \\
\text { injected }\end{array}$} & \multirow{2}{*}{$\begin{array}{l}\text { Amount of } \\
\text { fraction } \\
\text { injected } \\
\text { (mg protein) }\end{array}$} & \multirow{2}{*}{$\begin{array}{l}\text { No. of } \\
\text { animals }\end{array}$} & \multicolumn{2}{|c|}{ Eggs } & \multirow{2}{*}{$\begin{array}{c}\text { Light scattering of } \\
\text { outer region of } \\
\text { zonat }\end{array}$} \\
\hline & & & $\begin{array}{c}\text { No. } \\
\text { examined }\end{array}$ & $\stackrel{\%}{\text { fertilized } \dagger}$ & \\
\hline $\begin{array}{l}\text { Anti-ovary } \\
\text { serum } \\
\text { fraction } \\
\text { (AOSF) }\end{array}$ & $\begin{array}{r}4 \\
20 \\
30 \\
40 \\
50\end{array}$ & $\begin{array}{l}4 \\
3 \\
3 \\
3 \\
4\end{array}$ & $\begin{array}{l}74 \\
47 \\
52 \\
49 \\
61\end{array}$ & $\begin{array}{c}100 \cdot 0 \\
55 \cdot 3 \\
28 \cdot 8 \\
0 \\
0\end{array}$ & $\begin{array}{c} \pm \text { to }+ \\
++ \\
++ \\
+++ \\
+++\end{array}$ \\
\hline $\begin{array}{l}\text { Control } \\
\text { serum fraction } \\
\text { (CSF) }\end{array}$ & $\begin{array}{r}4 \\
20 \\
50\end{array}$ & $\begin{array}{l}3 \\
3 \\
3\end{array}$ & $\begin{array}{l}38 \\
41 \\
47\end{array}$ & $\begin{array}{l}100 \cdot 0 \\
100 \cdot 0 \\
100 \cdot 0\end{array}$ & $=$ \\
\hline
\end{tabular}

* Oestrous females were naturally or artificially inseminated and injected with serum fraction, then killed the next morning.

$\dagger$ All fertilized eggs were in the pronuclear stage with well-developed pronuclei, and all were monospermic. Unfertilized eggs showed no sign of sperm passage through the zona pellucida.

$\ddagger$ Examined under dark-field illumination: very strong $(+++)$, moderate $(++)$, weak $(+)$, faint $( \pm)$ and no $(-)$ light scattering.

AOSF- and CSF-injected animals continued to experience regular 4-day cycles, and were allocated to several groups. During each successive cycle for seven cycles one group of AOSF- and one group of CSF-treated animals were naturally or artificially inseminated during oestrus. The next morning, the eggs were examined for evidence of fertilization (Text-fig. 1). Each of the AOSFand CSF-treated animals had 10 to 15 eggs in the oviducts and all the eggs appeared normal. As Table 3 indicates, AOSF completely blocked fertilization during the first three oestrous cycles, and then gradually lost its fertilizationblocking activity. The fertility of the animals was almost completely restored by the 28th day, i.e. seven oestrous cycles, after the injection of AOSF. The CSF-injected animals (controls) always produced completely fertilizable eggs (Table 3). The zona surfaces of the eggs that were not fertilizable scattered light strongly and these zonae, unlike those of control eggs, were resistant to trypsin and mercaptoethanol. We occasionally observed actively motile, acrosomereacted spermatozoa within the cumulus masses or attached to the zona surfaces of infertilizable eggs.

In order to determine whether AOSF can bind to the zona surfaces of the ovarian oocytes, the following experiments were performed. Females were given an i.p. injection of AOSF (equivalent to 40 to $50 \mathrm{mg}$ protein/animal) at 09.00

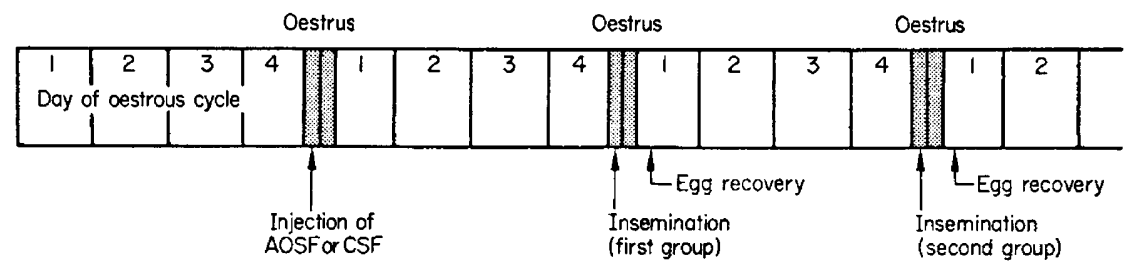

TEXT-FIG. 1. A scheme showing the schedule of injection of AOSF or CSF, insemination and egg recovery. Only the first two groups of experiments are shown. 
Table 3. Long-term effects of anti-ovary serum fraction on fertilization of hamster eggs in vivo*

\begin{tabular}{lcccc}
\hline \multirow{2}{*}{$\begin{array}{c}\text { Fraction injected } \\
\text { (50 mg protein/animal) }\end{array}$} & $\begin{array}{c}\text { Time of insemination } \\
\text { after serum fraction } \\
\text { injection (days) }\end{array}$ & $\begin{array}{c}\text { No. of } \\
\text { animals }\end{array}$ & & \multicolumn{2}{c}{ Eggs } \\
\cline { 3 - 5 } & & No. & examined & fertilized $\dagger$ \\
\hline Anti-ovary serum & 4 & 8 & 110 & 0 \\
fraction (AOSF) & 8 & 10 & 134 & 0 \\
& 12 & 4 & 58 & 0 \\
& 16 & 3 & 47 & $25 \cdot 5$ \\
& 24 & 3 & 51 & $82 \cdot 3$ \\
Control serum & 28 & 2 & 28 & $96 \cdot 4$ \\
fraction (CSF) & 4 & 3 & 49 & $100 \cdot 0$ \\
& 12 & 4 & 60 & $98 \cdot 3$ \\
& 24 & 2 & 29 & $100 \cdot 0$ \\
\hline
\end{tabular}

* Oestrous females were injected with serum fractions. They were naturally or artificially inseminated in the evening of oestrus (Day 4) of successive oestrous cycles and killed the next morning to reveal the condition of eggs (see Text-fig. 1).

$\dagger$ For explanation, see Table 2.

hours on Day 3 of the oestrous cycle and ovarian oocytes were collected at 12.00 to 14.00 hours the next day by puncturing the walls of the follicles and mechanically removing the cumulus cells surrounding the oocytes with a pair of needles. When the oocytes were examined under dark-field illumination, the surfaces of their zonae pellucidae scattered light strongly (Pl. 1, Fig. 5), thus indicating the binding of AOSF to the zona surfaces. This was further confirmed by injecting animals with fluorescein-conjugated AOSF (Pl. 1, Fig. 6).

\section{DISGUSSION}

The antigenicity of the egg and its envelopes has been long recognized as a result of studies on invertebrate species, and the possible block or disturbance of fertilization and embryonic development by antibodies against these antigens has been documented (Tyler, 1961; Metz, 1967). The antigenicity of mammalian

\section{EXPLANATION OF PLATE 1}

FIG. 1. Hamster egg treated in vitro with anti-ovary serum fraction (AOSF), showing light scattering of the outermost region of the zona pellucida (arrow) due to binding of AOSF. P, polar body. $\times 450$.

FIg. 2. Hamster egg treated in vitro with control serum fraction (CSF). The zona pellucida does not scatter light. $\times 450$.

FIG. 3. Mouse egg treated in vitro with AOSF. Unlike the zona pellucida of the AOSFtreated hamster egg, the zona of the mouse egg does not scatter light. P, polar body. $\times 450$.

FIG. 4. Rat egg treated in vitro with AOSF. The zona pellucida does not show light scattering. $P$, polar body. $\times 450$.

Fig. 5. Hamster ovarian oocyte showing light scattering of the outermost region of the zona pellucida (arrow) following an intraperitoneal injection of the female with AOSF. $\mathrm{Gv}$, germinal vesicle. $\times 450$.

Fig. 6. Hamster ovarian oocyte showing fluorescence of the outermost region of the zona pellucida (arrow) following an intraperitoneal injection of the female with fluoresceinconjugated AOSF. The fluorescence of the zona surface was fairly strong when first examined, but gradually faded away during photography. $\times 450$. 
PI..II: I

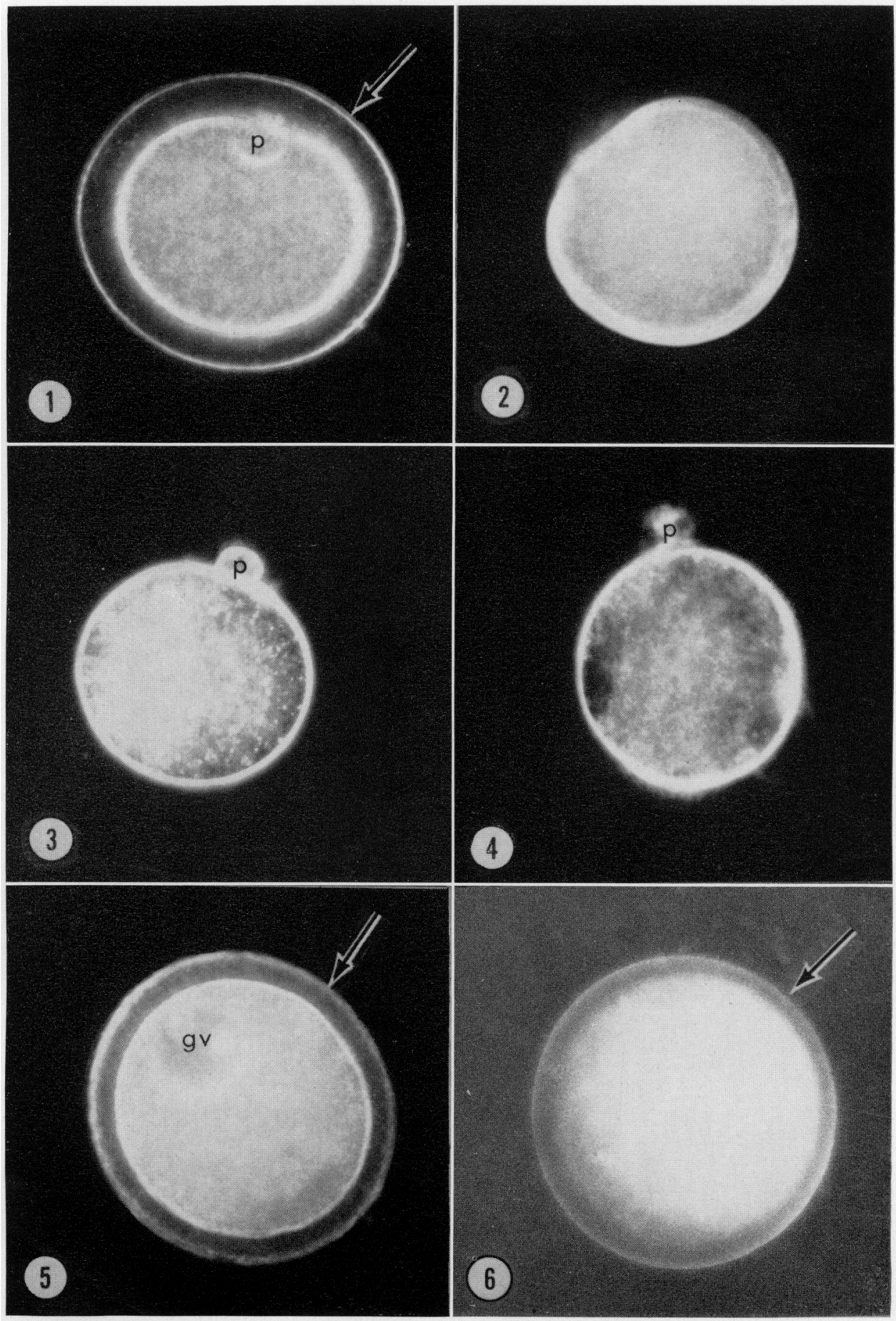

Firite 4.492 
ovaries, ovarian oocytes, unfertilized oviducal eggs and preimplantation embryos has been clearly demonstrated by Shivers and his co-workers (Ownby \& Shivers, 1972; Sacco \& Shivers, 1973a, b, c) and by Glass \& Hanson (1974) who all share the view that the zona pellucida is one of the most antigenic components in the ovary, egg and preimplantation embryo. The possible inhibition of hamster fertilization in vitro by anti-ovary or anti-zona pellucida sera or antibodies has been demonstrated (Shivers et al., 1972; Garavagno et al., 1974) and was confirmed in the present study. The results of our study have indicated that the AOSF injected into animals binds to the zona surfaces of the eggs and interferes with zona penetration by spermatozoa. The block to fertilization in vivo by the antibody appears to be due to interference with zona penetration by the spermatozoa rather than interference with the capacitation or transport of spermatozoa in the female genital tract. An unexpected finding was that the AOSF we used could pass through the ovarian follicles to bind to the zona pellucida of ovarian oocytes. The reported failure of antiserum (antibody) to pass through the cumulus cells surrounding excised ovarian oocytes (Garavagno et al., 1974) is puzzling.

The molecular mechanism by which anti-ovary antibody binds to the zona pellucida and prevents spermatozoa from entering the zona is unknown, but it is perhaps relevant to consider the mode of action of certain plant lectins which also bind to the zona pellucida, thereby rendering it impenetrable to spermatozoa (Oikawa et al., 1973, 1974). These lectins, like anti-ovary antibody, cause a 'precipitation' of the zona surface and render it resistant to zonadissolving agents (e.g. trypsin and mercaptoethanol) and impenetrable to spermatozoa. Most probably both the antibody and lectins bind to terminal saccharide residues of the zona glycopeptides and cause extensive cross-linking of adjacent saccharide chains in such a way that the zona-dissolving agents or sperm-borne zona lysin can no longer depolymerize the zona material (Oikawa et al., 1973, 1974). Since both the antibody and wheat germ lectin prevent sperm binding to the zona surfaces (Oikawa et al., 1973, 1974; Shivers et al., 1972; Garavagno et al., 1974), they may have some characteristics in common so that they attach to the sperm-binding sites on the zona pellucida, thus rendering them unavailable to the spermatozoa.

The lasting but not permanent fertilization-blocking effect of the anti-ovary antibody is noteworthy. It is unlikely that a large amount of the anti-ovary antibody injected persists in the body fluid of animals. The antibody is probably destroyed or eliminated from the animal's body within a few days after being injected, except for that bound to some specific structures or components such as the zona pellucida. The possible explanation for this persistence of effect over a definite time period is that the anti-ovary antibody can bind to the zona pellucida of ovarian oocytes that have reached or passed a specific stage of maturation. Before this stage is reached, the oocytes with a 'primordial' zona or no zona at the time antibody is injected will not bind or bind only a little to the antibody; thus when they mature and are released from the ovary, they can be fertilized normally. Therefore the antibody-induced sterility will persist from the time the antibody is injected until the time these latter oocytes are ovulated. 
In the present study we had to use very high doses of anti-ovary serum fraction (antibody) to induce a complete block of fertilization. This may be partly due to a dilution of the fraction by the animals' body fluid and partly due to a relatively low concentration of antibody in the fraction. Further studies using a highly purified antibody should be of great value in analysing the precise mechanisms of the antibody-mediated block to fertilization, and in evaluating the practical value of the antibody as a method for immunological control of fertilization.

Note added in proof. After this paper was submitted, Jílek \& Pavlok (1975) reported that antibodies against mouse ovaries blocked fertilization of mouse eggs both in vitro and in vivo.

\section{ACKNOWLEDGMENTS}

This work was supported by grants from the Ford Foundation, U.S. Public Health Service (HD-03402) and the Population Council. We thank Mrs Cherrie A. Mahi for her assistance in the preparation of the manuscript.

\section{REFERENCES}

Garavagno, A., Posada, J., Barros, C. \& Shivers, C.A. (1974) Some characteristics of the zona pellucida antigen in the hamster. F. exp. Zool. 189, 37-50.

GLASs, L.E. \& HANson, J.A. (1974) An immunologic approach to contraception: localization of antiembryo and antizona pellucida serum during mouse preimplantation development. Fert. Steril. $25,484-493$.

Greenwald, G.S. (1960) The effects of unilateral ovariectomy on follicular maturation in the hamster. Endocrinology 66, 89-95.

GreEnwald, G.S. (1961) Quantitative study of follicular development in the ovary of the intact or unilaterally ovariectomized hamster. $\mathcal{F}$. Reprod. Fert. 2, 351-361.

Jílek, F. \& Pavlok, A. (1475) Antibodies against mouse ovaries and their effect on fertilization in vitro and in vivo in the mouse. $\mathcal{F}$. Reprod. Fert. 42, 377-380.

Metz, C.B. (1967) Gamete surface components and their role in fertilization. In Fertilization, Vol. 1, pp. 163-236. Eds C. B. Metz \& A. Monroy. Academic Press, New York.

Otkawa, T., Yanagimachi, R. \& Nicolson, G.L. (1973) Wheat germ agglutinin blocks mammalian fertilization. Nature, Lond. 241, 256-259.

Oikawa, T., Nicolson, G.L. \& YanaGmachi, R. (1974) Inhibition of hamster fertilization by phytoagglutinin. Expl Cell Res. 83, 239-246.

OWNBY, C.L. \& ShIVERs, C.A. (1972) Antigens of the hamster ovary and effects of anti-ovary serum on eggs. Biol. Reprod. 6, 310-318.

SACco, A.G. \& Shrvers, C.A. (1973a) Localization of tissue-specific antigens in the rabbit ovary, oviduct and uterus by the fluorescent antibody technique. $\mathcal{F}$. Reprod. Fert. 32, 415-420.

Sacco, A.G. \& Shivers, C.A. (1973b) Comparison of antigens in the ovary, oviduct and uterus of the rabbit and other mammalian species. F. Reprod. Fert. 32, 421-427.

SAcco, A.G. \& Shrvers, C.A. (1973c) Effects of reproductive tissue-specific antisera on rabbit eggs. Biol. Reprod. 8, 481-490.

Shivers, C.A., Dudkizwicz, A.B., Franklin, L.E. \& Fussell, E.N. (1972) Inhibition of sperm-egg interaction by specific antibody. Science, $\mathcal{N} . Y .178,1211-1213$.

TYLER, A. (1961) Approaches to the control of fertility based on immunological phenomena. 7. Reprod. Fert. 2, 473-506.

Yanagimachi, R. (1966) Time and process of sperm penetration into hamster ova in vivo and in vitro. J. Reprod. Fert. 11, 359-370. 